\title{
PENERAPAN BAHAN AJAR MATEMATIKA BERBASIS RME TERHADAP KEMAMPUAN KOMUNIKASI DAN PENALARAN MATEMATIS
}

\author{
${ }^{1}$ Dede Indriani \\ ${ }^{1}$ Universitas Muhammadiyah Sukabumi \\ Dedeindriani123@ummi.ac.id
}

\begin{abstract}
Abstrak
Penelitian ini didasarkan pada permasalahan kemampuan komunikasi dan penalaran matematis di Indonesia tergolong rendah.Tujuan dari penelitian ini yaitu untuk mendeskripsikan bahan ajar matematika berbasis RME terhadap kemampuan komunikasi dan penalaran matematis siswa. Bahan ajar dibuat dengan menggunakan soal kontekstual dalam memperkenalkan konsep matematika. Metode penelitian yang digunakan dalam penelitian ini adalah metode kualitatif dengan jenis penelitian studi kepustakaan. Dari hasil tersebut dapat disimpulkan bahwa penggunaan bahan ajar matematika berbasis RME berpengaruh positif terhadap kemampuan komunikasi dan penalaran matematika, hal ini disebabkan karena dalam bahan ajar tersebut dapat (1) memfasislitasi siswa dalam mengkonstruksi pengetahuan meraka, (2) memahamai masalah kontekstual (3) menyelesaikan masalah kontekstual 4) mendiskusikan penyelesaian masalah 5) membuat kesimpulan
\end{abstract}

Kata Kunci : RME, bahan ajar matematika berbasis RME, kemampuan komunikasi dan penalaran matematis dan penalaran matematis siswa masih jauh dengan apa yang diharapkan. Kebanyan siswa masih lemah dalam

\section{PENDAHULUAN}

Dalam pendidikan matematika siswa seringkali merasa kesulitan dalam memahami dan mengungkapkan ide matematis yang diajarkan guru. Sedangkan matematika sebagai salah satu mata pelajaran yang di anggap penting dalam meningkatkankemampuan siswa. Kemampuan berfikir logis, kreatif, sistematis dan efeketif yang dikembangkan dalam bahan ajar matematika. Dalam permendiknas mata pelajaran matematika perlu diberikan pada semua peserta didik dari sekolah dasar. Maka dari itu matematika harus di pelajari harus dan dikembangkan di sekolah agar dapat dipahami dengan benar. Pada dasarnya pembelajran matematika sering dikatakan abstrak sehingga siswa mengalami kesulitan dalam belaajr matematika. Permendiknas Nomor 22 Tahun 2006 mengenai Standar Isi, mata pelajaran matematika bertujuan agar peserta didik memiliki kemampuan, sebagai berikut: 1) Memahami konsep dan mengaplikasikan konsep matematika; 2) Menggunakan penalaran pada pola dan sifat serta menjelaskan gagasan dan pernyataan matematika ; 3) Memecahkan masalah; 4) Mengkomunikasikan gagasan dengan symbol ; 5) Memiliki sikap menghargai kegunaan matematika dalam kehidupan. Dari tujuan tersebut, aspek penalaran dan komunikasi merupakan kemampuan yang harus dimiliki siswa sebagai standar yang patut dikembangkan.

Namun kenyataanya kemampuan komunikasi penalaran dan komunikasi siswa. Siswa kurang mampu menjelaskan ide-ide dalam bentuk tulisan dan gambar. siswa kurang mampu dalam mengemukakan ide-idenya sendiri dan siswa kurang mampu dalam menyampaikan pendapatnya di mata pelajaran. Hal tersebut didukung oleh laporan The Third International Mathematics and Sciencs (TIMSS) (2007) menyatakan bahwa Indonesia berada pada posisi 36 dari 48 nrgara disurvei dalam aspek komunkasi matematis dan National Council of Teacher of Mathematics atau NCTM merekomendasikan penalaran sebagai salah satu standar proses dari lima standar proses dalam pembelajaran matematika di sekolah. Seperti dikatakan, "in the middle grades students should have frequent and diverse experiences with mathematics reasoning as they evaluate conjecture, construct and evaluate mathematical arguments" (NCTM, 2000, p.262).

Menurut Ontario Ministry of Education's (2005, p.20) bahwa berkomunikasi matematika adalah menyampaikan makna melalui lisan, ditulis, dan bentuk visual (misalnya, memberikan penjelasan alasan atau pembenaran hasil secara lisan atau tertulis; mengkomunikasikan ide-ide matematika dan solusi secara tertulis, dengan menggunakan angka dan simbol aljabar, dan secara visual, menggunakan gambar, diagram, grafik, tabel, grafik, dan materi konkret). Karena itu dalam pembelajaran matematika siswa perlu dibiasakan untuk memberikan argumen 
setiap jawabannya serta memberi tanggapan atas jawaban yang diberikan oleh orang lain.

komunikasi dan penalaran matematika siswa perlu ditingkatkan yaitu dengan cara menggunakan pembelajaran yang tepat. Oleh karena itu perlu adanya suatu bahan ajar yang dapat membantu guru dalam mengembangkan kemampuan penalaran dan komunikasi siswa baik ditingkat SMP maupun SMA. Melalui bahan ajar yang tepat diharapkan mampu meningkatkan kemampuan siswa dalam bernalar dan berkomunikasi matematika. Pendekatan pembelajaran yang akan diterapkan memungkinkan digunakan sebagai perantara untuk dapat meningkatkan kemampuan penalaran dan kemampuan komunikasi matematis siswa.

Bahan ajar yang digunakan sebaiknya dapat memfasilitasi guru untuk dapat mentransfer nilai dan pengetahuan. Sehingga guru tidak hanya mentransfer pengetahuan tentang matematika tetapi juga siswa harus mampu menemukan apa yang sudah dipelajarinya apalagi dalam kehidupan seharihari. Maka pembelajaran yang tepat adalah dengan menggunakan penerapan bahan ajar berbasis RME. Menurut Wirama dkk (2014 : 2 ) pendekatan matematika realistic bukan tempat memindah matematika dari guru kepada siswa menembukan kembali ide dan konsep matematika melalui eksplorasi masalah-masalah nyata.

Penerapan bahan ajar matematika di Indonesia diharapkan mampu meningkatkan kemampuan matematis dan prestasi belajar matematika siswa. Penelitian yang dilakukan Sahat Saragih tahun 2007 menyatakan bahwa pendekatan matematika realistik lebih baik dalam meningkatkan kemampuan berpikir logis, komunikasi matematik dan sikap positif terhadap matematika. Menurut Murata (2006) pembelajaran yang diduga dapat menumbuhkembangkan kemampuan berpikir asal dengan melaksanakan pembelajaran konstruktivisme. Dalam kaitan pentingnya permasalahan di atas, menurut fruedenthal agar matematika bernilai, matematika harus dihubungkan dengan realitas, dengan dunia siswa dan dunia masyarakat. maka diterapkan pembelajaran matematika yang menggunakan bahan ajar matematika berbasis RME yang bertujuan untuk meningkatkan kemampuan penalaran dan komunikasi matematika siswa. Tujuan dari penelitian ini adalah untuk mengetahui bagaimana penerapan bahan ajar matematika berbasis RME terhadap kemampuan penalaran dan komunikasi siswa.

\section{KEMAMPUAN PENALARAN DAN KOMUNIKASI MATEMATIS SISWA}

\section{Kemampuan penalaran matematis}

Menurut Lither (2008), penalaran adalah pemikiran yang diadopsi untuk menghasilkan pernyataan dan mencapai kesimpulan pada pemecahan masalah yang tidak selalu berdasarkan pada logika formal sehingga tidak terbatas pada bukti. Dari pendapat diatas dapat disimpulkan bahwa pemikiran dihasilkan dari pernyataan dan dapat memperoleh kesimpulan yang memang sudah diasumsikan sebelumnya.

Para ahli mengklarifikasikan kemampuan penalaran kedalam beberapa jenis kegiatan bernalar yang berdasar pada proses penarik kesimpulan. Tujuan utama diberikannya pembelajaran matematika pada jenjang sekolah dasar sampai sekolah menegah adalah agar siswa mampu menggunakan pemikiran pola dan sifat konsep matematik yang bisa menjelaskan gagasan dengan symbol, gambar atau media lainya.

Penalaran matematika diperlukan untuk menentukan sebuah argumen matematika mana yang benar dan yang salah. Peranya matematika tidak hanya penting untuk melakukan pembuktian rumus saja, tapi setiap menyelesaikan soal matamatika memerlukan kemampuan penalaran. Penalaran dan matematika tidak dapat dipisahkan satu sama lain karena dalam menyelesaikan permasalahan matematika perlu kemampuan penalaran matematika.dalam penalaran siswa diharapkan dapat melihat bahwa matematika merupakan pembelajaran yang logis. Dengan begitu siswa akan merasa yakin dengan apa yang akan dipelajarinya.oleh karena itu guru harus mampu meningkatkan kemampuan penalaran matematika dengan pengembangan belajar yang berbeda-beda.

Pada penjelasan peraturan dirjen dikdasmen Nomor 506/kep/PP/2004 tentang rapor menguraikan bahwa indikator siswa yang memiliki kemampauan dalam penalaran matematika diantaranya yaitu :

1) Kemampuan Mengajukan dugaaan;

2) Kemampuan Melakukan manipulasi matematika;

3) Kemampuan Menarik kesimpulan;

4) Kemampuan Menarik kesimpulan;

5) Kemampuan Memeriksa kesahihan argument;

6) Kemampuan Menemukan sifat gejala metematis untuk membuat generalisai.

\section{Kemampuan komunikasi matematis}

Menurut Greenes dan schulman (1996:159)

menyatakan bahwa komunikasi matematik adalah kemampuan 
1) Menyatakan ide melalui ucapan, tulisan, demonstrasi, dan melukisnya secara visual dalam tipe berbeda ;

2) Kemampuan memahami, mmenafsirkan, dan menilai ide yang disajikan dalam tulisan, lisan, atau dalam bentuk visual;

3) Menkostruk, Menafsirkan dan menghubungkan bermacam- macam representasi ide dan hubunganya ;

Menurut Musfiqon (2012 :16) “ komunikasi merupakan kegiatan rutin setiap interaksi antara dua orang lebih. Pada hakekatnya setiap kegiatan untuk memindahkan ide atau gagasan dari pihak satu ke pihak lain, baik itu antar manusia, antara manusia dengan alam sekitarnya atau sebaliknya, di situ akan terjadi proses komunikasi “. Dalam penelitian Cita Dwi " komunikasi terjadi interasksi baik secara tertulis maupun lisan antara pemeberi pesan dan penerima pesan, interaksi yang terjadi dapat berlangsung searah, 2 arah ataubanyak arah ".

kegiatan yang tergolong pada komunikasi matematik menurut Sumarmo (2012) diantaranya yaitu ;

a. Menyatakan situasi, gambar, diagram, atau beda nyata ke dalam bahasa, symbol, idea, atau model matematik,

b. Menjelaskan idea, situasi, dan relasi matematika secara lisan atau tulisan,

c. Mendengarkan, berdiskusi, dan menulis tentang matematika,

d. Membaca dengan pemahaman suatu representasi matematika tertulis,

e. Mengungkapkan kembali suatu uraian atau paragraph matematika dalam Bahasa sendiri.

Dari pernyataan diatas dapat membantu dalam meningkatkan kemampuan komunikasi siswa yang tertuang dalam salah satu kompetensi lintas kurikulum ( Ratumanan, 2003 : 29), yakni siswa menggunakan Bahasa untuk memahami mengembangkan, dan mengkomunikasikan gagasan dan informasi, serta untuk berinteraksi dengan orang lain dan betapa pentingynya siswa memiliki kemampuan tersebut hal ini dikemukakan oleh penelitian yani ramdani (2012) kemampuan berkomuniaksi adalah penting dalam semua disiplin ilmu artinya bahwa seseorang harus dapat :

1) Membuat konsep,

2) Mengkomunikasikan mathematical thinking mereka secara koheren ( tersusun secara logis ) dan jelas kepada teman-temanya, guru dan oralng lain,

3) Mengananalisis dan menilai mathematical thingking dan staretgi yang dipakai orang lain,

Menggunakan Bahasa matematika untuk mengekspresikan ide-ide matmatika secara benar, Pentingnya komunikasi matematika diungkapkan juga oleh Lindquist dan Elliot (1996) yang menyatakan bahwa kita memerlukan komunikasi dalam belajar matematika jika hendak meraih secara penuh tujuan social seperti belajar seumur hidup dan matematika untuk semua orang. Tanpa komuniaksi dalam matematika maka kita akan sedikit memiliki keterangan, data, fakta tentang pemahaman siswa dalam melakukan proses dan aplikasi matematika.

Berdasarakan pendapat-pendapat diatas disimpulkan bahwa kemampuan komunikasi matematika adalah kemampuan untuk mempresentasikan permasalahan atau ide dengan menggunakan benda nyata, gambar serta dapat menggunakan symbol- siymbol matematika Adapun indicator kemampuan komunikasi matematis siswa menurut utari (2006) adalah :

(1) Mampu menguhubungkan benda nyata, gambar, dan diagram ke dalam ide matematika;

(2) Mampu menjelaskan ide, situasi dan relasi ke dalam matematis secara lisan, tulisan, dengan benda nyata, gambar, grafik dan aljabar;

(3) Mampu menyatakan peristiwa sehari-hari dalam Bahasa atau symbol matematika ;

(4) Mampu mendengarkan, berdiskusi, dan menulis tentang matematika;

(5) Mampu membaca presentasi matematika tertulis dan menyusun pertanyaan yang relevan; serta

(6) Mampu membuat konjektur, menyusun argument, merumuskan definisi dan generalisaisi.

\section{METODE PENELITIAN}

Metode penelitian yang digunakan metode kualitatif dengan jenis penelitian kepustakaan. Penelitian kepustakaan merupakan suatu jenis penelitian yang digusnakan dalam pengumpulan informasi dan data secara mendalam melalui berbagai literatur, buku, catatan, serta hasil penelitian sebelumnya yang relevan, untuk mendapatkan jawaban dan landasan teori mengenai masalah yang akan diteliti.

\section{HASIL DAN PEMBAHASAN}

Menurut penelitian mochamad farid Ubaidillah dkk Realistuik Mathematics Education (RME) adalah pendekatan pembelajaran matematika yang berasal dari belanda sejak tahun 1970-an dengan berlandaskan pada filosofi matematika sebagai aktivitas siswa (mathematic as human activity) yang merupkam salah satu penedekatan 
pemebelajaran yang menunjang keterlibatan siswa dalam kegiatan pembelajaran. Wijaya (2012 :21) merumuskana 5 karakteristi RME, yaitu :

(1) Penggunaan konteks

(2) Penggunaan model untuk matematisasi progresif,

(3) Pemanfaat hasil kontruksi siswa

(4) Interaktivitas

(5) Keterkaitan

Proses pembelajaran bukan hanya proses transfer gagasan anatara guru kepada siswa, pembelajaran merupakan suatu proses bagaimana guru memberikan kesempatan kepada siswa untuk melihat dan memikirkan gagasan yang diberikan. Bahan ajar merupakan salah satu komponen penting dalam proses pembelajaran siswa. Prastowo (2013 : 298) menyatakan bahwa bahan ajar merupakan segala informasi, alat, maupun teks yang disusun secara sistematis, yang menampilkan keseluruhan dari kompetensi yang dikuasai siswa, sehingga tercipta suasana yang meungkinkan siswa untuk belajar tidak hanya mengetahui, tetapi juga melakukan (learning to do), menjadi (learning to be), hidup bersama (learning to live together) dengan tujuan, perencanaa sekaligus implementasi kurikulum. Oleh karena itu pada bahan ajar yang dikembangkan ini siswa dihadapkan pada permasalahan yang dari proses pembelajaran dan membangun pengetahun dari gagasan matematis yang mereka dapatkan.

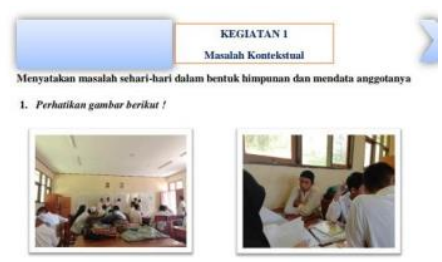

\section{Gambar 1 Layout Bahan Ajar}

Dari gambar diatas dapat dilihat bahwa dalam bahan ajar matematika berbasis RME, siswa dikenalkan dengan lingkungan sekitarnya ysng termasuk dalam kehidupan sehari-hari. Dalam gambar diatas salah satunya adalah lingkungan kelas. Kelas merupakan lingkungan tempat belajar siswa . dari gambar tersebut dapat terlihat himpunan kelas dianataranya adalah meja ,bangku, papan tulis tas dan buku.

Dengan adanya kaitan dalam pemblejaran matematika dengan lingkungan sekitar maka siswa akan lebih termotivasi dalam mempelajari matematika. Selain dikenalkan dengan pembelajaran yang dikaitkan dengan lngkungans sekitar. Bahan ajar LKS ini juga dikaitkan dengan permaslahan yang lebih luas lagi misalnya sebagai berikut :

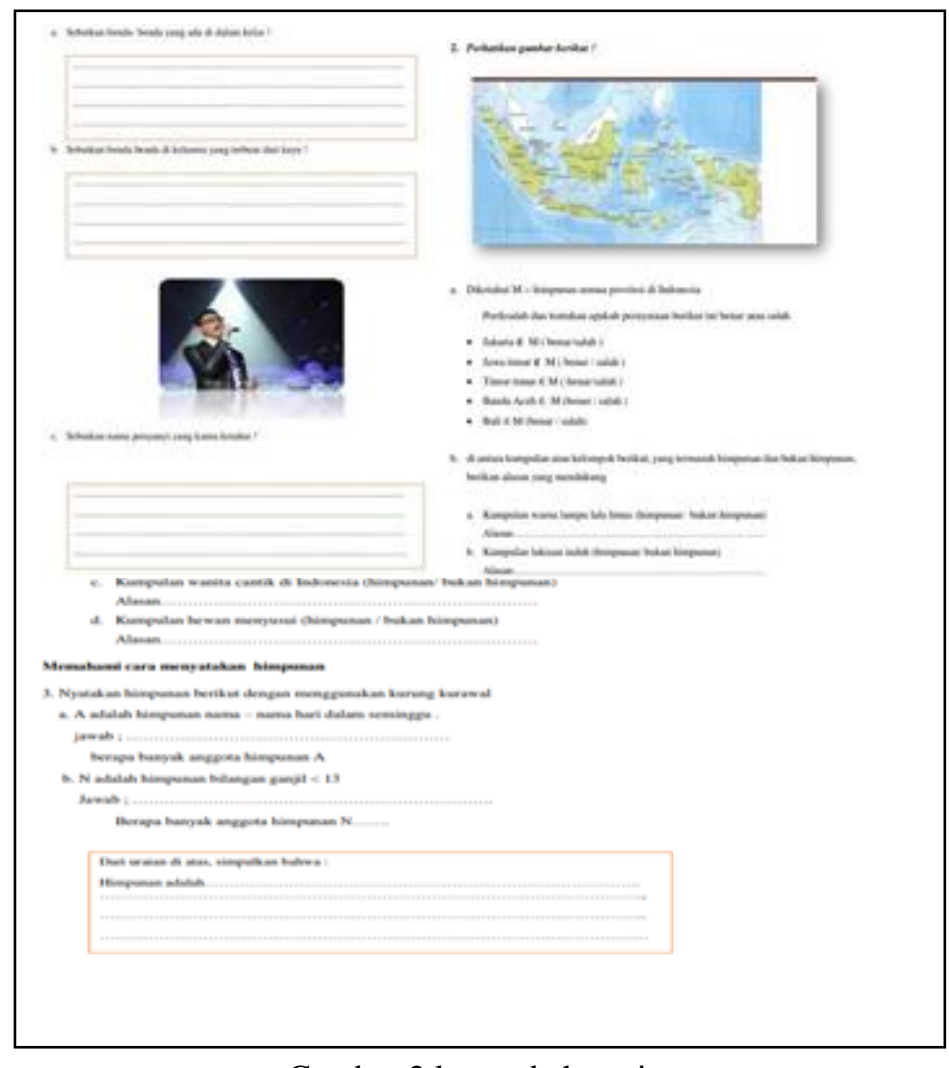

Gambar 2 layout bahan ajar

Siswa tidak hanya dikenalkan dengan lingkungan sekolah aja tapi siswa dikenalkan dengan permaslahan lainya yang beradaptasi di dunia yang sedang meraka jalani. Dalam bahan ajar ini siswa dituntut untuk memikirkan ide dalam mengkonstruksi sendiri pengetahuanya dengan lingkungan sekitarnya dan diuangkapkan secara matematis. Dalam permaslahan tersebut siswa dituntut untuk berpikir kritis agas dapt menyimpulkan informasi atau pengetahuan apa yang mereka dapatkan sehingga siswa mampu menghubungkan materi yang dirasa abstrak dengan kehidupan nyta dan mampu memfasilitsi siwa dalam mengkonstruksikan sendiri pengathuanya sehingga siswa merasakan kebermaknaan dalam pembelajaran. Oleh karena itu dengan bahan ajar berbasis RME ini dpat meningkatkan kemmpuan komunikasi dan penalaran matamti ssiswa dengan baik .

Dengan bahan ajar ini siswa dituntuu untuk mengkonstruksikan pengetahuanya dalam kehidupan nyata, sehingga siswa dapatm menemmukan kembali konsep matematika dala kedupan nyata yang sudah mereka pelahri dan dapat ditunagkan dalam kemampuan komuniaksi mamtematiknya. Misalnya siswa diberikan suatu maslah terkait himpunan suatu objek , maka siswa terlebih dahulu melihat keadaan 
sekeliling objek tersebut agar dapat menyelesaikan permaslahan yang diberikan. Dengan begitu siswa dpat memnemukan kembali konsep matematika di kehidupan disekitarnya,

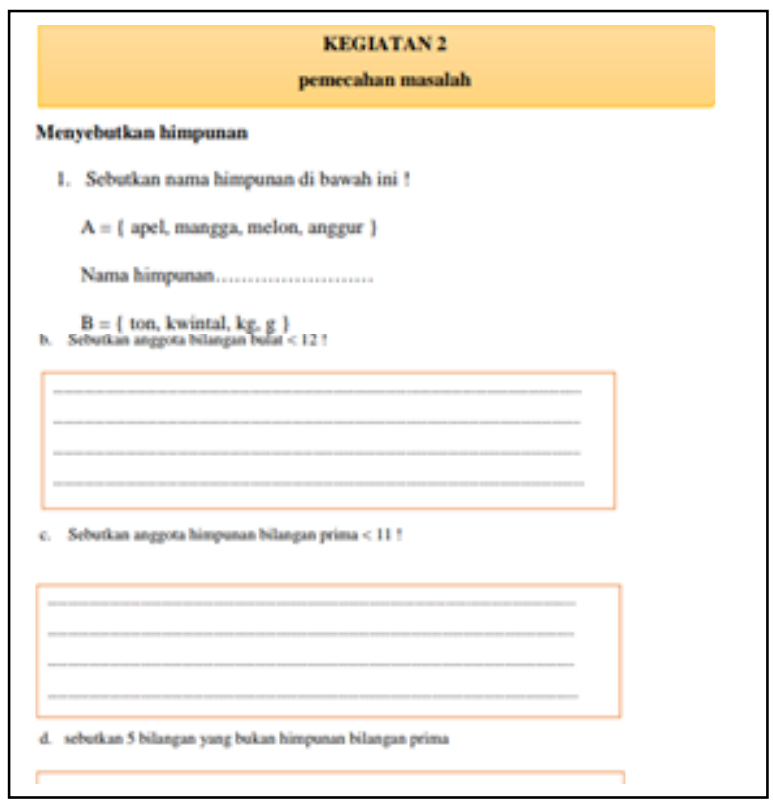

Gambar 3 layout bahan ajar

Dalam pembelajaran bahan ajar ini diharapkan mampu meningkatkan motivasi siswa dalam mempelajari matematika. Hal ini dikarenakan dengan mengunnakan bahan ajar berbasis RME, selalin siwa belajar dmatematika tapi isiwa juga belajar mwngenai pemahaman yang disekitarnya, serta siswa juga dibiasakan dalam memecakan permasalahan yang tepat dan efisien.

\section{KESIMPULAN}

Bahan ajar yang dapat meningkatan komunikasi dan pelaran siswa adalah bahan ajar yang menyajikan permasalahan terbuka serta merupakan permasalahan yang sering ditemukan siswa, yaitu permasalahan dalam kehidupan sehari-hari. Agar kemampuan komunikasi dan penalaran siswa berkembang maka selama proses pembelajaran berlangsung siswa diharapkan terlibat secara aktif dalam aktivitas matematik,

Berdasarkan hasil penelitian tersebut maka dapat disimpulkan bahwa penerapan bahan ajar matematika berbasis RME diharapkan dapat meningkatkan kemampuan penalaran dan komunikasi matematis siswa, hal ini disebabkan karena:

1. Bahan ajar tersebut memfasislitasi siswa dalam mengkonstruksi pengetahuan meraka.

2. Siswa diberikan permasalahan, agar memahamai masalah kontekstual

3. menyelesaikan masalah kontekstual
4. mendiskusikan penyelesaian masalah

5. membuat kesimpulan

\section{REKOMENDASI}

Dari hasil penelitian ini diharapkan dapat digunakan sebagai alternatif dalam meningkatkan kualitas pembelajaran matematika di sekolah. Selain itu diharapkan terdapat penelitian lanjutan terkait penerapan bahan ajar matematika berbasis RME untuk kemampuan matematis yang lainnya. Berdasarakan penelitian maka peneliti bisa sampaikan bahwa guru dapat lebih mengembangkan bahan ajar nya sehingga dapat berpegngaruh pada peningkatan kemampuan komunikasi dan penalaran matematis siswa.

\section{REFERENSI}

Zaini, Ahmad dkk . 2014. Perbandingan Keefektifan Pembelajaran Matematika Dengan Pendekatan Matematika Realistik Dan

Konvensional Ditinjau Dari Kemampuan Penalaran Dan Komunikasi Matematik Siswa. Jurnal Riset Pendidikan Matematika. Vol. 1(2) hal No.152-154.

Noviani, Dian dkk 2016. Penerapan Pembelajaran Matematika Realistic Berbantuan Geogebra Untuk Meningkatkan Kemampuan Komunikasi Mtaematis Siswa Smp.jurnal pendidikan matematika Vo. 5 (2) hal 45-46. ISSN 20864280

Puspitasari, Indri W dkk. 2019 Penerapan PBL Dengan RME Berbatuan Software Geogebra Untuk Meningkatkan Kemampuan Berfikir Logis Matemati Siswa SMP. Jurnal on Education Vol.1(4)hal 679-687.

Astuti, Anggraeni. Peran kemampuan Komuniaksi matematika Terhadap Prestasi Belajar Matematiaka Siswa. Jurnalformatif. Vol.2(2) hal 102- 110. ISSN: 2088351x

Nuraeni,Reni. Mengembangkan Kemampuan Komunikasi Matematik Siswa Melalui Stratefi Think Talk Write. Junral pendidikan matematika Vol. 5(2) hal 101-104. ISSN : 2086 